\title{
Treatment of barley straw with ammonia or urea solutions and digestibility of its structural carbohydrate fractions in sheep
}

\author{
J. Kowalczyk \\ The Kielanowski Institute of Animal Physiology and Nutrition, \\ Polish Academy of Sciences \\ 05-110 Jablonna, Poland
}

(Received 9 May 1994; accepted 12 May 1994)

\begin{abstract}
Barley straw with a 13 or $35 \%$ moisture content was treated on a laboratory scale with $5.25 \mathrm{~g}$ of urea $/ 100 \mathrm{~g} \mathrm{DM}$ at 20 or $40^{\circ} \mathrm{C}$ for 5 or 10 weeks with or without urease. The higher moisture content resulted in a 14 percentage units increase in straw degradability, whereas the lower moisture levcl gave 7 units of improvement in relation to untreated straw. Urease addition, elevation of temperature or prolonged treatment time were less effective. Significant amounts of added urea avoided decomposition during treatment.

Barley straw with an approximately $25 \%$ moisture content was treated under field conditions with a $25 \%$ ammonia solution $(2.6 \mathrm{~kg} \mathrm{NH} / 100 \mathrm{~kg})$ or with a $40 \%$ urea solution $(5.0 \mathrm{~kg}$ urea/ $/ 100 \mathrm{~kg}$ straw DM) for 6 weeks with a straw temperature of about $15^{\circ} \mathrm{C}$.

Twenty one-year-old wethers of about $46 \mathrm{~kg}$ body weight, in 4 groups of five, were fed untreated barley straw to appetite $(540 \mathrm{~g} / \mathrm{d})$, ammoniated straw $(550 \mathrm{~g} / \mathrm{d})$, ammoniated straw to appetite $(790 \mathrm{~g} / \mathrm{d})$ or urea-treated straw to appetite $(550 \mathrm{~g} / \mathrm{d})$, respectively, for one month.

Ammonia treatment decreased the structural carbohydrate fractions content but significantly increased the nitrogen content, straw intake and nutrient digestibility, whereas urea treatment gave only slight straw upgrading. Degradability in situ of ammoniated straw DM was about 9.2, but urea-treated only 1.5 percentage units higher than untreated straw. Animals fed ammoniated straw to appetite gained about $60 \mathrm{~g} /$ day during the experimental period whereas animals fed untreated and urea-treated straw, offered to appetite, or rationed ammoniated straw lost about $100 \mathrm{~g} /$ day demonstrating that only ammonialed straw fed to appetite covered the maintenance level of nutrient requirement. Urea was poorly hydrolyzed to ammonia during treatment at dominating in this region climatic conditions $\left(15^{\circ} \mathrm{C}\right)$ which was demonstrated in the high urea content in urea-treated straw and what could be the reason for inconsiderable straw upgrading with the applied method.
\end{abstract}

KEY WORDS: sheep, ammoniated straw, urea, structural carbohydrate, digestibility 


\section{INTRODUCTION}

Research on the treatment of cereal straw with ammonia and its use in ruminant feeds began 60 years ago (Kornberger, 1933). Chomyszyn et al. (1964) showed that treatment of straw with an ammonia solution doubled its content of crude protein ( $\mathrm{N} \times 6.25$ ), upgraded fibre and protein digestion, increased body weight gain and the utilization of nutrients, as compared to normal straw feeding. These results were verified in numerous works, and the utilization of straw in ruminant feeding is widely recognized in many countries (Borhami and Sundstøl, 1982; Sundstøl and Coxworth, 1984). Urea was also used for ammoniating straw, as it degrades to ammonia with bacterial urease present in the straw (Rashiq, 1979; Cloete et al., 1983, 1984; Williams et al., 1984a, 1984b; Dias da Silva and Sundstøl, 1986; Besle et al., 1989; Chestnut et al., 1988; Castrillo et al., 1991; Dulphy et al., 1992).

The aim of this study was to find the best conditions for treatment of straw with urea and compare its nutritive value with those of straw ammoniated with an ammonia solution, as well as to estimate the digestibility of structural carbohydrate fractions of ammoniated straw.

\section{MATERIALS AND METHODS}

\section{Treatment of straw with a solution of urea under laboratory conditions}

Barley straw was milled with a $2 \mathrm{~mm}$ hole diameter of sieve. The ground straw, containing about $87 \% \mathrm{DM}$, was divided into two parts, to one water was added so that the final dry matter content was $65 \%$. Portions of straw were then placed in $500 \mathrm{ml}$ tightly closed plastic jars. Urea was added in the amount of $5.25 \mathrm{~g} / 100 \mathrm{~g}$ DM of straw, and urease in an amount capable of degrading the urea to $160 \mathrm{mg}$ of ammonia in $3 \mathrm{~h}$ ( 2 tablets, Polish Chemical Reagents, Gliwice). Six types of samples were thus obtained:

CD - control, dry;

CW - control wet;

UD - treated with urea, dry;

UED - treated with urea and urease, dry;

UW - treated with urea, wet;

UEW - treated with urea and urease, wet.

Two samples of each kind were kept for either 5 or 10 weeks at room temperature 20 or $40^{\circ} \mathrm{C}$. In all samples DM, total nitrogen by the Kjeldahl method, urea and ammonia nitrogen by the Conway method (1962), were estimated. Degradability of straw DM was determined in the rumen for $72 \mathrm{~h}$ using the nylon bags method (Mehrez and Ørskov, 1977). 
Treatment of barley straw with ammonia or urea solution under field conditions

Winter barley straw was treated with a $25 \%$ ammonia solution in a proportion of $26 \mathrm{~kg} \mathrm{NH}_{3}$ for 1 ton of straw, or with a $40 \%$ solution of urea at a proportion of $50 \mathrm{~kg}$ of urea for 1 ton of straw. The control straw was treated with water in an amount equal to ammonia or urea solutions (about $75 \mathrm{~kg}$ ). The straw was kept in piles under plastic sheet for 6 weeks from mid-September to the end of October, with a temperature of about $15^{\circ} \mathrm{C}$ inside the straw piles.

Twenty wethers with a body mass of $40 \mathrm{~kg}$ were divided into four groups by the analogue method and fed individually for 31 days with untreated, ammoniated, or urea-treated barley straw as the only feed with an addition of a vitamin-mineral mixture. After opening the piles the straw was aired for a few days until the smell of ammonia disappeared. The animals in group A received untreated straw to appetite $(540 \mathrm{~g} / \mathrm{d})$; group B - ammoniated straw, in an amount similar as that consumed in group $\mathrm{A} ; \mathrm{C}$ - ammoniated straw to appetite $(790 \mathrm{~g} / \mathrm{d})$; and group D - urea-treated straw to appetite $(550 \mathrm{~g} / \mathrm{d})$. Feed was given twice a day with constant access to water. After a 31-day period of feeding, the digestibility of straw nutrients was estimated by the classic method of 6-day faeces collection.

The nutrient content in the samples of straw and faeces was estimated by the Weende method; ADF, NDF, ADL by the Goering and van Soest method (1970), hemicellulose by the difference between NDF and ADF, and cellulose by the Hoffman and Nehring method (1969).

The kinetics of digestibility of untreated, ammonia- or urea- treated straw were estimated by the in situ method, using $4,8,24,48$, and $72 \mathrm{~h}$ straw digestion, according to Mehrez and Ørskov (1977).

\section{RESULTS}

\section{Treatment of straw with urea solution}

Samples of urea-treated dry straw contained significant amounts of unhydrolyzed urea and only a small amount of ammonium nitrogen. On the other hand, in wet samples of urea-treated straw in analogical conditions, only small amounts of unhydrolyzed urea and higher levels of ammonia nitrogen were found. Decomposition of urea to ammonia at higher temperatures gave better results than at room temperature (Table 1). Samples of wet straw not treated with urea grew mouldy during their storage, whereas dry and wet urea-treated straw did not mould. 
TABLE 1

Unhydrolyzed urea-N and ammonia-N content in dry (D) and wet (W) straw treated with urea (U) and urease enzyme (E) in laboratory conditions, $\mathrm{g} / 100 \mathrm{~g} \mathrm{DM}$

\begin{tabular}{lcccc}
\hline & \multicolumn{4}{c}{ Urea treatment period } \\
\cline { 2 - 5 } Treatment & 5 weeks at temperature & \multicolumn{1}{c}{10 weeks at temperature } \\
& $20^{\circ} \mathrm{C}$ & $40^{\circ} \mathrm{C}$ & $20^{\circ} \mathrm{C}$ & $40^{\circ} \mathrm{C}$ \\
\hline & \multicolumn{4}{c}{ urea-N } \\
UD & 1.47 & 1.38 & 1.50 & 1.17 \\
UED & 1.31 & 1.27 & 1.58 & 1.23 \\
UW & 0.24 & 0.17 & 0.38 & 0.05 \\
UEW & 0.16 & 0.24 & 0.43 & 0.26 \\
& & \multicolumn{4}{c}{ ammonia-N } \\
UD & 0.22 & 0.28 & 0.26 & 0.46 \\
UED & 0.51 & 0.37 & 0.36 & 0.43 \\
UW & 1.43 & 1.41 & 1.59 & 1.37 \\
UEW & 1.49 & 1.31 & 1.49 & 1.32 \\
\hline
\end{tabular}

TABLE 2

Dry matter degradability of straw, treated with urea at different conditions, incubated in the rumen for $72 \mathrm{~h}$

\begin{tabular}{|c|c|c|c|c|}
\hline \multirow{3}{*}{ Treatment $*$} & \multicolumn{4}{|c|}{ Urea treatment period } \\
\hline & \multicolumn{2}{|c|}{5 weeks at temperature } & \multicolumn{2}{|c|}{10 wecks at temperature } \\
\hline & $20^{\circ} \mathrm{C}$ & $40^{\circ} \mathrm{C}$ & $20^{\circ} \mathrm{C}$ & $40^{\circ} \mathrm{C}$ \\
\hline CD & 53.9 & 53.4 & 54.6 & 55.2 \\
\hline $\mathrm{CW}$ & 54.5 & 54.3 & 52.9 & 54.3 \\
\hline UD & 54.9 & 58.8 & 56.8 & 60.1 \\
\hline UED & 56.9 & 59.4 & 57.4 & 61.7 \\
\hline UW & 60.2 & 64.7 & 64.5 & 68.8 \\
\hline UEW & 63.3 & 65.4 & 65.2 & 67.7 \\
\hline
\end{tabular}

* CD - control, dry; CW - control, wet; UD - treated with urea, dry; UED - treated with urea and urease enzyme, dry; UW - treated with urea, wet; UEW - treated with urea and urease enzyme, wet

Treatment of straw with urea under laboratory conditions caused an increase in the digestibility of straw dry matter by about 14 in wet and 7 percentage units in dry samples. Extending the duration of urea treatment in all cases gave a product with a higher DM digestibility, especially when treated straw contained a higher moisture content. Increasing the temperature of urea treatment to about $40^{\circ} \mathrm{C}$ resulted in slightly higher degradability of the obtained product than when treated at $20^{\circ} \mathrm{C}$. The addition of urease to urea treatment of straw did not significantly influence the digestibility of straw (Table 2). 
Feeding straw treated with ammonia solution or urea

The chemical composition of straw (Table 3 ) was altered after treatment with ammonia or urea solution. The crude protein $(\mathrm{N} \times 6.25)$ content was doubled. In ammoniated straw the amount of NDF, hemicellulose and lignin decreased. In ammoniated straw much of the ammonia was found in the form of ammonium salt; in urea-treated straw only a small amount of ammonia, but about $2 \%$ of urea were found. The feed intake (Table 4) when fed ammoniated straw given to appetite was about $43 \%$ higher than untreated straw. Intake of urea treated straw, fed to appetite, was similar to the amount in the control group given untreated straw (Table 4).

Sheep in groups A, B, D lost body mass during the experiment (Table 4), whereas animals receiving ammoniated straw to appetite (group $\mathrm{C}$ ) gained some $(\mathrm{P}<0.01)$.

Apparent digestibility coefficients of nutrients (Table 4) were highest in groups $\mathrm{B}$ and $\mathrm{C}$, and significantly lower in groups $\mathrm{A}$ and $\mathrm{D}(\mathrm{P}<0.01)$. The values of the apparent digestibility coefficient of lignin depended on the lignin content in straw and faeces taken for calculation, which was different before and after ammonia treatment. When the lignin contents determined in untreated straw and faeces were taken for calculations, a coefficient of 11.8 was obtained, when the contents of lignin determined in ammoniated straw but non-ammoniated faeces were used, the coefficient was 4.5 , and when content of lignin determined in ammoniated straw and ammoniated faeces were used, the coefficient was 14.2.

TABLE 3 Chemical composition of untreated,ammonia or urea treated straw in field conditions, $\mathrm{g} / \mathrm{kg} \mathrm{DM}$

\begin{tabular}{lccc}
\hline & \multicolumn{3}{c}{ Barley straw treated with } \\
\cline { 2 - 4 } Component & control & ammonia & urea \\
\hline Dry matter & 862 & 867 & 859 \\
organic matter & 926 & 916 & 921 \\
crude protein $(\mathrm{N} \times 6.25)$ & 51 & 106 & 119 \\
ammonia-N & - & 10 & 1 \\
urea-N & - & - & 10 \\
crudc fibre & 436 & 429 & 431 \\
ADF & 553 & 538 & 543 \\
NDF & 835 & 783 & 827 \\
ADL & 109 & 92 & 104 \\
hemicellulose & 282 & 245 & 284 \\
cellulose & 392 & 375 & 382 \\
N-free extractives & 429 & 411 & 405 \\
\hline
\end{tabular}


TABLE 4

Apparent digestibility coefficients of nutrients, straw intake and daily gain in sheep fed untreated, ammonia or urea treated straw as the only feed

\begin{tabular}{lcccc}
\hline & Control & \multicolumn{2}{c}{ Ammonia treated } & \multirow{2}{*}{ Urea treated } \\
\cline { 2 - 4 } Group & $\mathrm{A}$ & restricted & to appetite & \\
\cline { 2 - 4 } Apparent digestibility coefficients, $\%$ & $\mathrm{~B}$ & $\mathrm{C}$ & $\mathrm{D}$ \\
\hline organic matter & $45.0^{\mathrm{Aa}}$ & $58.2^{\mathrm{B}}$ & $54.0^{\mathrm{B}}$ & $48.0^{\mathrm{Ab}}$ \\
crude protein & $10.1^{\mathrm{A}}$ & $49.3^{\mathrm{B}}$ & $43.4^{\mathrm{C}}$ & $48.5^{\mathrm{B}}$ \\
N-free extractives & $41.4^{\mathrm{A}}$ & $56.7^{\mathrm{B}}$ & $51.6^{\mathrm{B}}$ & $43.5^{\mathrm{A}}$ \\
crude fibre & $54.0^{\mathrm{A}}$ & $69.2^{\mathrm{B}}$ & $65.2^{\mathrm{B}}$ & $54.8^{\mathrm{A}}$ \\
NDF & $51.8^{\mathrm{A}}$ & $68.8^{\mathrm{Ba}}$ & $64.7^{\mathrm{Bb}}$ & $54.7^{\mathrm{A}}$ \\
ADF & $48.8^{\mathrm{A}}$ & $60.9^{\mathrm{B}}$ & $58.2^{\mathrm{B}}$ & $52.9^{\mathrm{A}}$ \\
cellulose & $54.5^{\mathrm{A}}$ & $70.0^{\mathrm{B}}$ & $65.4^{\mathrm{B}}$ & $57.4^{\mathrm{A}}$ \\
hemicellulose & $57.6^{\mathrm{A}}$ & $86.4^{\mathrm{B}}$ & $79.0^{\mathrm{C}}$ & $60.6^{\mathrm{A}}$ \\
ADL & $11.8^{\mathrm{A}}$ & $2.0^{\mathrm{B}}$ & $3.2^{\mathrm{B}}$ & $9.7^{\mathrm{A}}$ \\
Feed intake, DM g/day & $538^{\mathrm{A}}$ & $553^{\mathrm{A}}$ & $787^{\mathrm{B}}$ & $554^{\mathrm{A}}$ \\
Body gain, g/day & $-92^{\mathrm{A}}$ & $-92^{\mathrm{A}}$ & $+63^{\mathrm{B}}$ & $-101^{\mathrm{A}}$ \\
\hline
\end{tabular}

$\mathrm{a}, \mathrm{b}-\mathrm{P}<0.05 ; \mathrm{A}, \mathrm{B}, \mathrm{C}-\mathrm{P}<0.01$

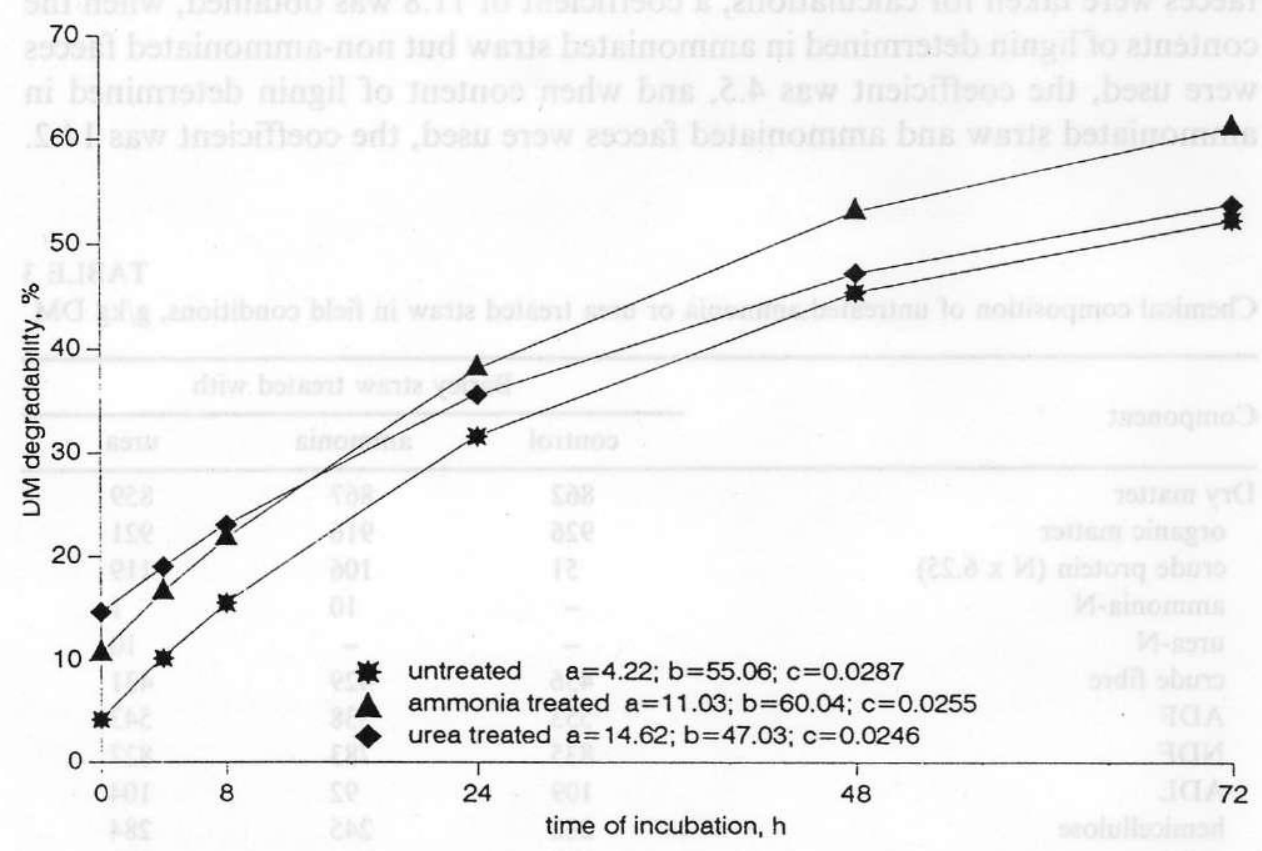

Fig. 1. Dry matter degradability of untreated, ammonia or urea treated straw in nylon bags placed in the rumen of sheep 
This shows the imperfection of methods of lignin estimation and its undefined and labile composition.

Straw treated with ammonia solution incubated in nylon bags in the rumen was digested $(71.1 \%)$ more effectively $(\mathrm{P}<0.01)$ than untreated straw $(59.3 \%)$, or that treated with urea $(61.6 \%)$ (Fig. 1).

\section{DISCUSSION}

Cereal straw fed to appetite as the only feed for cattle or sheep does not cover the maintenance requirements of ruminants even if properly supplemented with minerals and vitamins because of the shortage of nitrogen and energy supplied from fermented carbohydrate. Treatment of straw with ammonia increases nitrogen content and structural carbohydrate availability. Straw can be sufficiently upgraded this way to achieve low levels of production in sheep and cattle (Sundstøl and Coxworth, 1984).

Urea treatment may be a cheaper, widely available and much safer to handle alternative. Rashiq (1979) and Dias da Silva and Guedes (1990) treated different straws with $55 \mathrm{~g}$ urea $/ \mathrm{kg}$ straw and found increases of degradability in situ of between 10 and 20 percentage units. Jayasuriya and Pearce (1983), Williams et al. (1984b) and Dias and Silva et al. (1988) did not find a response in digestibility to the addition of urease. By contrast, Bestle et al. (1989) reported that addition of urease increases urea hydrolysis and straw degradability by 2 to 5 percentage units when compared to treatments without urease. Results obtained in the present study (Table 3) show only a slight improvement in degradability, about 1-2 percentage units, due to the urease addition. The presence and activity of microbial origin urease on straw subjected to treatment is widely changeable due to climatic and environmental factors, which could explain the variability in urease influence on treatment effectiveness.

Cloete and Kritzinger (1984) considered treatment with urea lasting 4 to 6 weeks at $22-24^{\circ} \mathrm{C}$ or $1-2$ weeks at $35^{\circ} \mathrm{C}$ enough to obtain improvements. Jayasuriya and Pearce (1988) reported that even to 2-4 days could be sufficient with an addition of urease. In our experiment an increase in straw degradability in relation to duration of urea treatment for 5 or 10 weeks was 2-4 percentage units, showing that the straw upgrading process was rather slow at 20 or even at $40^{\circ} \mathrm{C}$. Information on the influence of environmental temperature over urea treatment is rather poor and imprecise. Higher temperature accelerates hydrolysis of urea but, to obtain optimum digestibility, a temperature of about $20^{\circ} \mathrm{C}$ is recommended by Williams et al. (1984b). In our conditions, increase of treatment temperature from 20 to $40^{\circ} \mathrm{C}$ resulted in straw degradability improvement of $2-5$ percentage units. 
Moisture content in treated straw is an important factor influencing urea treatment effectiveness. Values between 20 and $60 \%$ of moisture are recommended as acceptable (Cloete and Kritzinger, 1984; Cottyn and de Boever, 1988; Dias da Silva et al., 1988; Williams et al., 1984a). This statement was confirmed by our results, as the increase of moisture from 13 to $35 \%$ resulted in an upgrade in urea-treated straw degradability by $6-8$ percentage units.

Effectiveness of straw upgrading by treatment with ammonia in solution or gaseous form has been well documented and various technology procedures have been proposed (Chomyszyn et al., 1964; Sundstøl and Coxworth, 1984). The procedure for treatment with urea is more difficult to establish, however, as its results depend on the rate and amount of urea hydrolyzed to ammonia, which in turn is a function of moisture, temperature, time of exposure and urease enzyme presence. These factors are often difficult to control in the practice of treatment. Numerous experiments (Dulphy et al., 1992; Craig et al., 1988; Chestnut et al., 1988), including our results (Tables 1 and 3), have demonstrated that a significant amount of added urea avoided decomposition. Neverthless, straw becomes significantly enriched in nitrogen (Table 3), but the increase of available energy from structural carbohydrate not always follows the nitrogen increase, as fibre and its fractions or organic matter digestibility are smaller after urea than after ammonia treatment (Table 4). Ammonia treatment decreases crude fibre and its fractions and particularly lignin content, which can be ascribed mainly to the phenolic acids released from the fibre structure (Theander and $\AA$ man, 1984). Changes in fibre fractions content after treatment with urea are less pronounced. Digestibility of the lignin component in sheep is variable and could be, to some extent, explained by its hydrolysis in the digestive tract of ruminants, mainly in the rumen with phenolic acids release. Another explanation of this variability could be that during ammonia treatment, cross-linking covalent bonds of the cellulose-lignin complex became susceptible to chemicals during the analytical procedure. It seems that the lignin fraction estimated analytically in ammoniated straw is "purer" than in untreated straw or in faeces.

Significantly higher intake and digestibility of ammoniated than untreated straw has been observed in many experiments and confirmed with the data of Table 4. Higher digestibility of structural carbohydrate fractions at lower straw intake than to appetite feeding can be explained with the known negative correlation between the level of nutrient intake and their digestibility. Intake of urea treated straw in sheep to appetite was established at the level of untreated straw and digestibility of nutrients in these groups of animals was also close and significantly lower than for ammoniated straw (Table 4) indicating very low effectiveness of urea treatment on straw upgrading in field conditions. The reason for that could be the unfavourable climatic conditions, because the temperature of the environment at treatment time in autumn was, as usual in this 
region, low, depressing urease activity. The high content of unhydrolyzed urea and low of ammonia in urea treated straw support this statement.

\section{CONCLUSIONS}

Treatment of straw with ammonia results in a decrease of structural carbohydrate fractions but also in a significant improvement of digestibility of organic matter and structural carbohydrate fractions, whereas urea treatment gives only slight effects.

The moisture content in straw for treatment, duration of treatment, environmental temperature, presence of adequately active urease are all important factors influencing the extent of straw upgrading in the urea treatment.

\section{REFERENCES}

Besle J.M., Chenost M., Tiesserand J.L., Lemoine J.P., Faurie F., Grenet N., 1989. Ammoniation of straw by urea: extent of ureolysis and improvement of nutritive value at low levels of added water. V Journée de Recherche sur l'Alimentation des Herbivores, INRA

Borhami B.E.A., Sundstal F., 1982. Studies on ammonia treated straw. The effect of type and level of ammonia, moisture content and treatment time on digestibility in vitro and enzyme soluble organic matter of oat straw. Anim. Feed Sci. Technol. 7, 45-51

Castrillo C., Fondevila M., Alibes X., Joy M., 1991. Chemical treatments for upgrading lignocelullosic resources and strategies for their utilization in ruminant fecding. In: G.C. Galleti (Editor). Production and Utilization of Lignocellulosics. Elsevier, Amsterdam, pp. 339-373

Chestnut A.B., Berger L.L., Fahey G.C.Jr., 1988. Effects of conservation methods and anhydrous ammonid or urea treatments on composition and digestion of tall fescue. J. Anim. Sci. 66, 2044-2056

Chomyszyn M., Ziołecka A., Kużdowicz M., Buraczewski S., Kowalczyk J,, 1964. The use of ammoniated feeds in the feeding of ruminants. 10. Ammoniated straw in rations for sheep (in Polish). Rocz. Nauk rol., 84B, 75-81

Cloete S.W.P., de Villiers T.T., Kritzinger N.M., 1983. The effect of ammoniation by urea on the nutritive value of wheat straw for sheep. S. Afr. J. Sci. 3, 143-146

Cloete S.W.P., Kritzinger N.M., 1984. A laboratory assessment of various treatment condition affecting the ammoniation of wheat straw by urea. S. Afr. J. Sci. 14, 55-58

Conway E.J., 1962. Microdiffusion Analysis and Volumetric Error. Crosby, Lockwood and Son, Ltd. London

Cottyn B.G., De Boever J.L., 1988. Upgrading of straw by ammoniation. Anim. Feed Sci. Technol. $21,287-294$

Craing W.M., Ulloa J.A., Watkins K.L., Nelson B.D., 1988. Effects of level, form and time of urea application on the nutritive value of Alicia Bermuda grass. J. Anim. Sci. 66, 185-193

Dias da Silva A.A., Guedes C.W.M., 1990. Variability in the nutritive values of straw cultivar of wheat, rye and triticale, and response to urea treatment. Anim. Feed Sci. Technol. 28, 79-89 
Dias da Silva A.A., Sundstøl F., 1986. Urea as a source of ammonia for improving of nutritive value of wheat straw. Anim. Feed Sci. Technol. 14, 67-79

Dias da Silva A.A., Mascharenhas-Fereira A., Guedes C.W.M., 1988. Effect of moisture level, treatment time and soya bean addition on the nutritive value of urea treated maize stover. Anim. Feed Sci. Technol. 19, 67-77

Dulphy J.P., Jamot J., Chenost M., Besle J.M., Chiofalo V., 1992. The influence of urea treatment on the intake of wheat straw in sheep. Ann. Zootech. 41, 169-185

Goering H.K., Van Soest P.J., 1970. Forage Fibre Analysis. Apparatus. Reagents. Procedures and Some Application. Ars Agric. Handbook, USDA, 379

Hoffmann B., Nchring K., 1969. Untersuchungen zur Welterentwicklung der Futtermittelanalyse. 2. Die Bestimmung der Kohlenhydrate in der Futtermitteln. Arch. Tierernähr. 19, 651-670

Jayasuriya M.N., Pearce G.R., 1983. The effect of urease enzyme on treatment time and nutritive value of straw treated with ammonia as urea. Anim. Feed Sci. Technol. 8, 271-281

Kornberger M., 1933. Zur Aufschliessung des Stroches durch Ammoniak im Stalldunger. Prakt. Bl. Pflanzenbau 10, 255-268

Mahrez A.Z., Ørskov E.R., 1977. The study of the artificial fibre bag technique for determining the digestibility of feeds in the rumen. J. Agric. Sci., Camb. 88, 645-650

Rashiq M.H., 1979. Urea treatment of wheat straw. Report on FAO Postgraduate Course in Animal Science 1978/79. Royal Veterinary and Agricultural University, Copenhagen, Denmark

Sundstøl F., Coxworth E.M., 1984. Ammonia treatment. In: F. Sundstøl, E. Owen (Editors), Straw and Other Fibrous By-products as Feed. Elsevier, Amsterdam, pp. 196-247

Theander O., Åman P., 1984. Anatomical and chemical characteristics. In: F. Sundstøl. E. Owen (Editors), Straw and Other Fibrous By-products Feed. Elsevier, Amsterdam, pp. 45-78

Williams P.E.V., Innes G.M., Brewer A., 1984a. Ammonia treatment of straw via hydrolysis of urea. 1. Effect of dry matter and urea concentration on the rate of hydrolysis of urea. Anim. Feed Sci. Technol. 11, 103-113

Williams P.E.V., Innes G.M., Brewer A., 1984b. Ammonia treatment of staw via hydrolysis of urea. 2. Addition of soya bean (urease), sodium hydroxide and molasses, effects on the digestibility of urea treated straw. Anim. Feed Sci. Technol. 11, 115-124

\section{STRESZCZENIE}

Sloma traktowana roztworem amoniaku lub mocznika i strawność jej węglowodanów strukturalnych u owiec

Słomę jęczmienną o wilgotności 13 lub 35\% traktowano, w skali laboratoryjnej, mocznikiem w ilości $5,25 \mathrm{~g} / 100 \mathrm{~g}$ suchej masy słomy z dodatkiem lub bez dodatku ureazy przy tcmperaturze 20 lub $40^{\circ} \mathrm{C}$ w ciągu 5 lub 10 tygodni. Strawność suchej masy mocznikowancj słomy o większej wilgotności, oznaczona metodą in situ była większa o 14 jednostek, a słomy o mnicjszej wilgotności o 7 jednostek niz słomy zwykłej. Dodatek ureazy, zwiększenie temperatury lub przedłużenie okresu działania mocznika wplywały w mniejszym stopniu na polepszenie strawności. Znaczna ilość dodanego do słomy mocznika nie ulegala rozkładowi w okresie preparowania słomy.

Slomẹ jęczmienną o wilgotności $25 \%$ traktowano w warunkach polowych $25 \%$ roztworem amoniaku (2,6 kg NH$/ 100 \mathrm{~kg}$ suchej masy słomy) lub $40 \%$ roztworem mocznika ( $5 \mathrm{~kg}$ mocznika/100 kg suchej masy słomy) i trzymano pod folią plastikową przcz 6 tygodni przy średniej temperaturze slomy $15^{0} \mathrm{C}$. 
Dwadzieścia jednorocznych skopów o masie ciala około $46 \mathrm{~kg}$ podzielono na cztery grupy i żywiono pryez 31 dni, odpowiednio w grupach, sieczką ze słomy zwykłej do woli (540 g), słomą amoniakowaną $(550 \mathrm{~g})$, słomą amoniakowaną do woli $(790 \mathrm{~g})$ lub do woli słomą traktowaną mocznikiem $(550 \mathrm{~g})$, jako jedyną paszą $z$ dodatkiem mieszanki vitaminowo-mineralncj.

Zawartość frakcji węglowodanów strukturalnych po traktowaniu amoniakiem uległa zmniejszeniu, zwiększyły się natomiast istotnie zawartośc azotu i jego pobranie przez owce oraz strawność składników pokarmowych. Traktowanie slomy mocznikiem spowodowało niewielkie polepszenie jakości słomy. Strawność amoniakowancj suchej masy słomy oznaczona metodą in situ zwiększyła się o 9,2, a słomy mocznikowanej zaledwie o 1,5 jednostek w porównaniu ze słomą zwykłą. Skopy żywione słomą amoniakowaną do woli powiększyły w okresic doświadczenia masę ciała o około 60 g/dzień, natomiast zywione do woli słomą zwykłą lub mocznikowaną bądź słomą amoniakowaną w ograniczonej ilości traciły na wadze, co wskazuje, że tylko słoma amoniakowana skarmiana do woli pokrywała, a nawet nieco przewyższala, zapotrıcbowanie bytowe na składniki pokarmowe.

Mocznik dodany do stomy tylko w niewielkicj ilości ulegał hydrolizie do amoniaku w panujących warunkach klimatycznych $\left(15^{\circ} \mathrm{C}\right)$, co mogło być przyczyną niezadowalającego polepszenia wartości pokarmowej słomy po mocznikowaniu. 